\title{
La dirección de centros y sus metáforas: símbolo, acción y ética.
}

\section{Estudio de un Caso}

The direction of centers and its metaphors: symbol, action and ethics. Case study.

Se trata del estudio de la dirección escolar y su práctica en la vida cotidiana de los centros educativos, utilizando la metáfora como instrumento de análisis. Son cuatro los grandes temas que se abordan: a) el acceso a la función directiva y el modelo de dirección; b) el ámbito de la acción directiva (dimensión dinámica) definido por la confianza, la razón y los sentimientos (con especial atención en la soledad como sentimiento particularmente vinculado a la dirección); c) la ética en la práctica directiva y el papel del silencio como instrumento micropolítico en la organización escolar, identificando toda serie de silencios posibles, y d) la práctica de la acción directiva en la que se analiza el tiempo y su vivencia en el trabajo de la dirección (el tiempo multidimensional de la acción directiva) y las tareas directivas interpretadas y analizadas desde la dimensión práctica de la acción directiva.

Para ello, se ha llevado a cabo una investigación etnográfica con estudio de un caso en un centro de Primaria de la provincia de Cádiz (España).
PALAVRAS-CHAVE: Metáfora; simbolismo; ética; organização e administração; escolas. KEY WORDS: Metaphor; symbolism; ethics; organization and administration; schools. PALABRAS-CLAVE: Metafora; simbolismo; etica; organización y administración; escuelas.

Rosa Vázquez Recio

Teses de Doutorado, 2002

Facultad de Ciencias de la Educación.

Universidad de Cádiz

<rmaria.vazquez@uca.es>

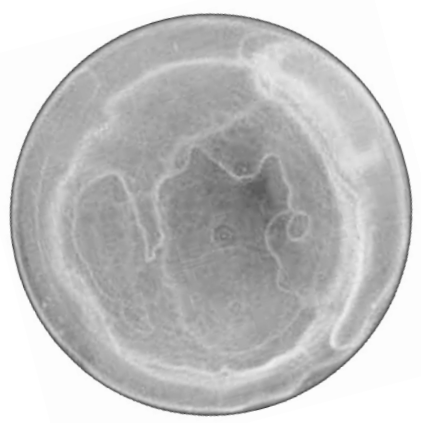

Recebido para publicação em: 13/06/02 Aprovado para publicação em: 19/06/02

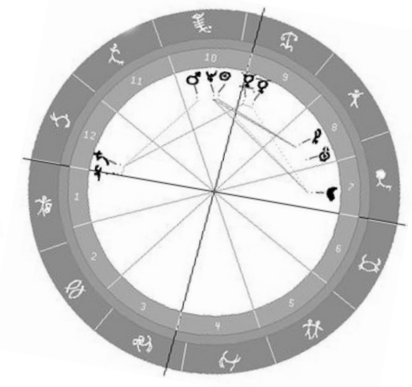

